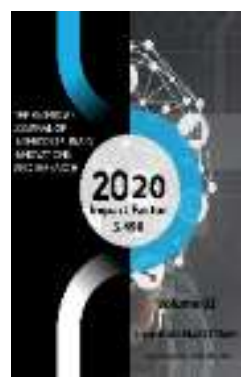

\title{
Stockpiling And Chips Nature Of Substance Treated Potatoes Under Standard Condition
}

\author{
Nath Pathak \\ Tribhuvan University, Institute Of Agriculture And Animal Science, Kathmandu, Nepal \\ Tetsuya Yamada \\ Tribhuvan University, Institute Of Agriculture And Animal Science, Kathmandu, Nepal
}

Journal Website:

http://usajournalshub.c

om/index,php/tajiir

Copyright: Original content from this work may be used under the terms of the creative commons attributes 4.0 licence.

\section{ABSTRACT}

The medicines were duplicated threefold. Evidently sound tubers $>60$ gram weight after various substance medicines were put away in bamboo racks and wooden plate, separately at Kumaltar and Daman for 120 days. Perceptions were recorded on weight reduction rate, growing rate, numbers and weight of fledglings and quality boundaries for chips. Twofold fumigation with CIPC was viable for restraint of growing and decrease of postharvest misfortune as long as 120 days in both the areas. Then again the better shade of the chips was created by multiple times hydrogen peroxide treated potatoes.

\section{KEYWORDS}

Potato stockpiling, growing, Post-reap treatment, hydrogen peroxide, calcium chloride, chips handling

\section{INTRODUCTION}

The high temperature and lack of time for preparing ranchers urge to deal their item at least following reaping. The semi short-lived and massive nature of potato tubers are exposed to nonstop weight reduction and growing during stockpiling. For putting away potatoes, cold store is ideal for holding significant stretch.

Indigenous techniques for potato stockpiling (spreading tubers under floor, putting away in canisters and hanging in bamboo containers and so on) are most savvy and acknowledged 
by Nepalese ranchers for transient stockpiling to get better cost. Be that as it may, growing and weight reduction are serious issues in these techniques because of higher temperature. Growing causes incredible weight reduction and diminishes tuber quality. Weight misfortunes because of growing and decaying have been assessed from 10-40\% under on-ranch stockpiling condition in India.

To defeat growing and higher weight reduction countless synthetic compounds, for example, ethylene, nonanol, chlorprophan, maleic hydrazide $(\mathrm{MH})$, carvone,abscisic corrosive, indole acidic corrosive, clove oil, mint oils, hydrogen peroxide maleic hydrazide, $(\mathrm{MH})$ have been tried and utilized in numerous nations since quite a while past. Among them the utilization of CIPC hold business significant in world for sprout concealment and better quality support. Kleinkopf et al. Single treatment with CIPC@ 40 -60 ml t-1 of potato was successful for stifled fledgling development and decreased stockpiling misfortune as long as 90 days under pile (18-32 ${ }^{\circ} \mathrm{C}$ and $52-88 \%$ R.H) and pit stockpiling (19-27 ${ }^{\circ}$ ( and 69-92 \% R.H.) Nonetheless, its viability on field pressure potato, fluctuating temperature and stickiness away may cause disappointment of fledgling hindrance. Numerous basic oils (Spearmint oil, Peppermint oil, Mint oil, Clove oil and so on) separated from plant materials indicated great option in contrast to CIPC for sprouts concealment. These oils have been ensured and are being utilized for natural potato creation. Frazier and Kleinkopf additionally detailed that hydrogen peroxide and its subsidiaries were discovered climate amicable and are permitted by the government natural norms. These elective mixes are false "sprout inhibitors" but rather harm the creating sprouts and smother sprout prolongation.

\section{MATERIALS AND STRATEGIES}

1. Fumigation with CIPC @ $40 \mathrm{ml}$ ton-1 potato before capacity.

2. Fumigation with CIPC @ $40 \mathrm{ml}$ ton-1 potato before capacity and 45 days after capacity.

3. Fumigation with hydrogen peroxide@ @ $40 \mathrm{ml}$ ton-1 potato before capacity.

4. Fumigation with hydrogen peroxide@40 ml-1 to1n potato before capacity and 45 days after capacity.

5. Fumigation with calcium chloride @ 40 ml-1 ton potato-1 preceding stockpiling.

\section{Growing Rate}

Third arrangements of perceptions were recorded on growing rate, quantities of fledglings per tuber, sprout weight (g kg-1 tubers) at 30 days stretches after development of fledglings. A tuber was viewed as grown when it had in any event one fledgling estimating $5 \mathrm{~mm}$ long.

\section{Decreasing Sugars}

Decreasing sugars was dictated by utilizing dinitrosalicyclic colorimetric strategy by recording the absorbance perusing in spectrophotometer at $575 \mathrm{~nm}$. To figure the milligram diminishing sugars per 100 gram new weight of potato, a standard bend was plotted with various centralization of glucose $(0.00125$, $0.0025,0.05,0.01,0.02$, and $0.04 \mathrm{mg}$ glucose$1 \mathrm{ml}$ water on $\mathrm{X}$-pivot and retentive perusing on Y-hub. The retentive perusing of tests were recorded and aligned based on standard bend 
and introduced as milligram lessening sugars per 100 gram new weight of potato.

\section{Chips Characteristics}

The fifth arrangements of perception were recorded on chips characteristics as chips tone, freshness, taste and by and large agreeableness of chips. For assurance of chips characteristics, arbitrarily chose 10 potato tubers were stripped and cut into cuts of 1.4 $\mathrm{mm}$ thickness with a hand worked slicer. Great and flawless cuts were washed completely in virus water to eliminate the surface starch and sugars. These cuts were spread in paper towel to eliminate surface water and afterward singed quickly in palm oil at $180^{\circ} \mathrm{C}$ till halting of the air pockets.

\section{Growing And Fledgling Weight}

The growing was seen following 60 days of capacity at Khumaltar and following 90 days at Daman. Medicines contrasted fundamentally on growing rate at 60,90 and 120 days after capacity in mid slope. At 60 days, control treatment had the greatest growing (52.9\%) while there was no growing on different medicines. At 90 days the most extreme growing rate $(59.50 \%)$ was likewise seen on control treatment and it was the base (2.60\%) on multiple times fumigation with CIPC. At 120 days of capacity, growing rate contrasted fundamentally among the medicines at Khumaltar. At Daman, growing was altogether varied at 90 and 120 days of capacity.

Growing of tubers during capacity brought about extensive expansion in absolute weight reduction because of vanishing. Fledglings itself is the immediate weight reduction and higher penetrability, higher surface zone of fledglings and quicker metabolic exercises additionally expanded loss of water from the potatoes. He revealed that utilization of CIPC decreased growing of potato in pile stockpiling and no growing in pits. Additionally, the impact was more at higher elevation which was as a result of the lower temperature. The higher dry issue and explicit gravity on control treatment in this investigation could be because of vanishing of more water through fledglings. Dry issue rate and explicit gravity when capacity regardless of synthetic medicines was higher in the potatoes which were filled in high slope.

\section{REFERENCES}

1. Hartmans KJ. Measurable Data on Nepalese Horticulture, AgriBusiness Advancement and Insights Division, Service of Farming and Cooperatives, Singha Durbar, Kathmandu, Nepal 2016.

2. El-Moniem EAAA, Abd-Allah ASE. In: Every other month Farming (ed.), Horticulture data and correspondence Center, Kathmandu, Nepal. Uncommon Issue, Global Potato Year 2010; 15(8): 201-209.

3. Nuriel E.. Public Potato Advancement Program, Khumaltar, Nepal 2012.

4. Al-Mughrabi. Handling characteristics of potato assortments developed at two areas and put away at 5, 11 and 140 C. Potato J 2009; 21(4-8): 214-223. 
5. Singh B, Ezekiel R. Changes of decreasing sugar in potato genotypes during cold stockpiling and their chips quality. In Proc. Public Workshop on Agriculture, fourth, Kathmandu, Nepal 2008; pp. 321-324.

6. Sharma PK. Fledgling Restraint away: Current status, new sciences and normal compound. Am J Potato Res 2007; 50: 547-567.

7. Singh B, Ezekiel R, Kumar D. CIPC deposits on put away Chestnut Burbank potatoes: most extreme name application. Am Potato J 1999; 54: 327357. 